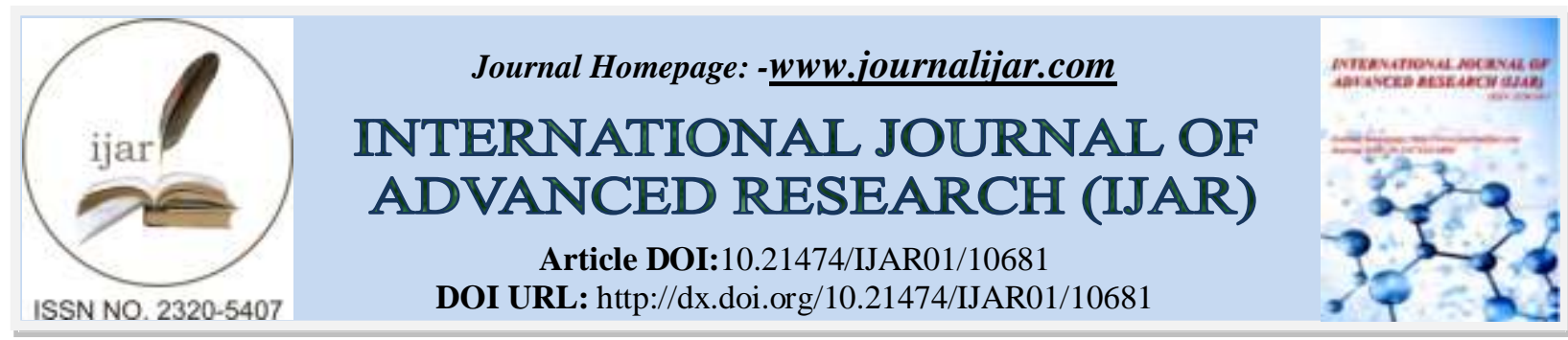

RESEARCH ARTICLE

\title{
FACTORS AFFECTINGSMALLHOLDER FARMERS' PARTICIPATION AND LEVEL OF PARTICIPATION IN SMALL SCALE IRRIGATION: THE CASE OF DEDER DISTRICT OF EASTERN HARARGHE ZONE, ETHIOPIA
}

\author{
Bedasso Urgessa $^{1}$, Fekadu Beyene ${ }^{2}$ and Chaneyalew Seyoum ${ }^{2}$ \\ 1. Fedis Agricultural Research Center, Oromia Agricultural Research Institute. \\ 2. Department of Rural Development and Agricultural Extension, Haramaya University.
}

\section{Manuscript Info}

Manuscript History

Received: 17 January 2020

Final Accepted: 20 February 2020

Key words:-

Smallholder Farmers, Participation,

Heckman Two-Stage, Small-Scale

Irrigation, Deder District
Published: March 2020

\begin{abstract}
Irrigation systems require active involvement of the community for sustainable operation to meet the intended objectives. However, farmers' participation in small-scale irrigation in Ethiopia has largely been peripheral. Therefore, this study identified and analyzed, the socio- economic and institutional factors affecting participation of smallholder farmers in small-scale irrigation and its effect on household income in Deder district of East Hararghe Zone. Two stage sampling procedure was used to select sample respondents.First, irrigation user kebeles were identified and four sample kebeles were randomly selected. At the second stage, 150 sample respondents were selected usingstratified sampling, probability proportion to size and simple random sampling method.A cross-sectional survey method was used and data was collected through semi-structured interview schedule. Descriptive statistics and Heckman's two-stage estimation model were used for dataanalysis. The analysis revealed that sex of the household head, availability of family labor force,total livestock holding and access to extension service are significant factors affecting both participation in small-scale irrigation and irrigation income. Whereas, distance from household's residence to the water source, size of cultivated land andperceived soil fertility status are significant factors affecting participation in small scale irrigation and land under irrigation is significantly affect irrigation income.Application ofthe right agricultural practice is important to increase agricultural productivity and production. Irrigation is one means by which agricultural production can be increased to meet the growing food demands. Therefore, smallholder farmers should be assisted and encouraged to participate in small-scale irrigation thereby improve their production and income.
\end{abstract}

Copy Right, IJAR, 2020,. All rights reserved.

\section{Introduction:-}

Agriculture is the most important economic activity in many developing countries providing food, employment, foreign exchange and raw materials for industries. Nearly 1.5 billion people are engaged in smallholder agriculture across the world. Agriculture comprises $75 \%$ of the world's poorest people, whose food, income and livelihood 
prospects depend on agriculture (Ferris, 2014). Agriculture has agreater contribution to reduce poverty and food insecurity in a mass form than any other intervention (FAO, 2015). By 2050, Africa's population will be 2.1 billion people and its food demand is expected to triple in response to this growth putting adevastating pressure on agriculture to feed the people and create jobs (Jayne et al., 2017).

Agriculture is the mainstay of the majority of the population living in Sub-Saharan Africa. However, SSA countries are characterized by low agricultural productivity. This is related to the fact that the sector is predominantly rain fed, which is in most cases unreliable resulting poor yields and the changing weather conditions would further aggravate the situation, exposing small farmers to negative impact of climate change (Todaro, 2012).

Ethiopia is one of SSA countries, where economy is dominated by agriculture in which large number of its population is directly or indirectly involved (FAO, 2015). The sector is contributing about $42 \%$ of GDP, $85 \%$ of the employment, $90 \%$ of the export earnings and $70 \%$ of the supply of industrial raw materials (World Bank, 2010). Nevertheless, Ethiopia's agriculture continues to face many challenges. Adverse climatic conditions, erratic distribution and unreliable rainfall, lack of appropriate land use system resulting in soil and other natural resources degradation (Spielman et al., 2010). Ethiopia needs to double its cereal production by 2025 in order to meet the food needs of its rapidly growing population (IWMI, 2005). The challenge is how to meet the increasing food demand with the existing but declining natural resource base under worsening climatic conditions. The varying climate is also the major challenges affecting agricultural production in eastern Hararghe in general and Deder district in particular. It is important to apply the right agricultural practices in order to increase agricultural productivity and production. Irrigation is one means by which agricultural production can be increased to meet the growing food demands. It has the potential to increase both yields and cropping intensity (Awulachew et al., 2010; FAO, 2014).

Expanding small-scale irrigation is a policy priority in Ethiopia in general and Oromia region in particular for rural livelihood improvement, poverty alleviation and growth as well as climate adaptation (MoA, 2011). Irrigation contributes to livelihood improvement through increased income, food security, employment opportunity, social needs fulfillment and poverty reduction (Asayehegn, 2012). Irrigated agriculture limits crops failure, external shocks and increases yield thus leading to improved income and better food security (Pinstrup, 2011). Hence, investing in small-scale irrigation is one of the strategies to improve production levels especially for small holder farmers.Farmers' participation in small-scale irrigation in Ethiopia has largely been peripheral (Awulachew and Ayana, 2011; FAO, 2015). The weak participation of farmers in most African countries left behind poor financial andtechnical capacity of farmers (Namara et al., 2011 and Mutambara et al., 2014). Irrigation systems require active involvement of the community for their sustainable operation. Therefore, thisstudy is focused on assessment of factors affecting smallholder farmers' participation in small scale irrigation and its effect on household income.

\section{Methodology:-}

\section{Description of the Study Area:}

The study was conducted at Deder district of East Hararghe administrative zone which contains 37 rural kebeles and 3 urban kebeles. Geographically, the district is located in eastern part of Oromia National Regional State between $9^{\circ} 09^{\prime} \mathrm{N}-9^{\circ} 24^{\prime} \mathrm{N}$ latitude and $41^{\circ} 16^{\prime} \mathrm{E}-41^{\circ} 32^{\prime} \mathrm{E}$ longitude. The capital town of the district is Deder town, which located $112 \mathrm{~km}$ west of Harar town, and $12 \mathrm{~km}$ from the main road that takes from Harar to Addis Ababa (DANR, 2018). Agro-climatically, it encompasses highland (33\%), midland (50\%) and lowland (17\%) with altitudes ranging from 1200 to 3138 meters above sea level. The temperature of the area ranges from $14^{\circ} \mathrm{C}$ Min. to $29^{\circ} \mathrm{C}$ Max and annual average rainfall ranges from $600 \mathrm{~mm}$ in the lowland to nearly $1200 \mathrm{~mm}$ in the highland. The district covers a total 67428 ha land out of which $39.3 \%$ is used for cultivation, $0.7 \%$ for grazing, $21.4 \%$ for forest plantation, bush and shrubs, and $17.7 \%$ for residential and $20.9 \%$ is Rugged and mountains. (DANR, 2018).

Agriculture is the major economic activity in the rural area, mixed farming system being a common practice in all agro-climatic zones (highland, midland and lowland). Maize is a staple crop in the district followed by sorghum. Wheat and barley are also the second major category of food crops produced in the highland part of the district. Legumes such as haricot bean and faba bean are grown usually intercropped with maize and sorghum (DANR and DLA, 2018).Besides rain fed agriculture, irrigation agriculture is being practiced in the district. The district has a wide range of water sources which are underutilization for both traditional and modern irrigation systems. Traditional irrigation systems have a long history in the district. However, modern irrigation systems were introduced during the Derg period, in the 1970s. Currently, there are a number of traditional and modern irrigation systems in the district. The modern scheme has cemented main irrigation canals which help to reduce water loss 
through seepage. There are 9771ha total irrigation coverage with 21437 irrigation user households in the district. 2165 households which are about $11 \%$ of total users have been using modern irrigation schemes. These cover only 554ha land which are $6.7 \%$ of total irrigation land. Traditional irrigation systems cover $89 \%$ in terms of users and $93.7 \%$ in terms of area coverage. The main sources of the district irrigation water are river and spring water. The major vegetables and fruits produced under irrigation are: potato, sweet potato, papaya, banana, tomato, carrot, cabbage, coffee, khat, sugarcane and garlic (DIDA, 2018). Map of the study area was shown in figure 1 below.

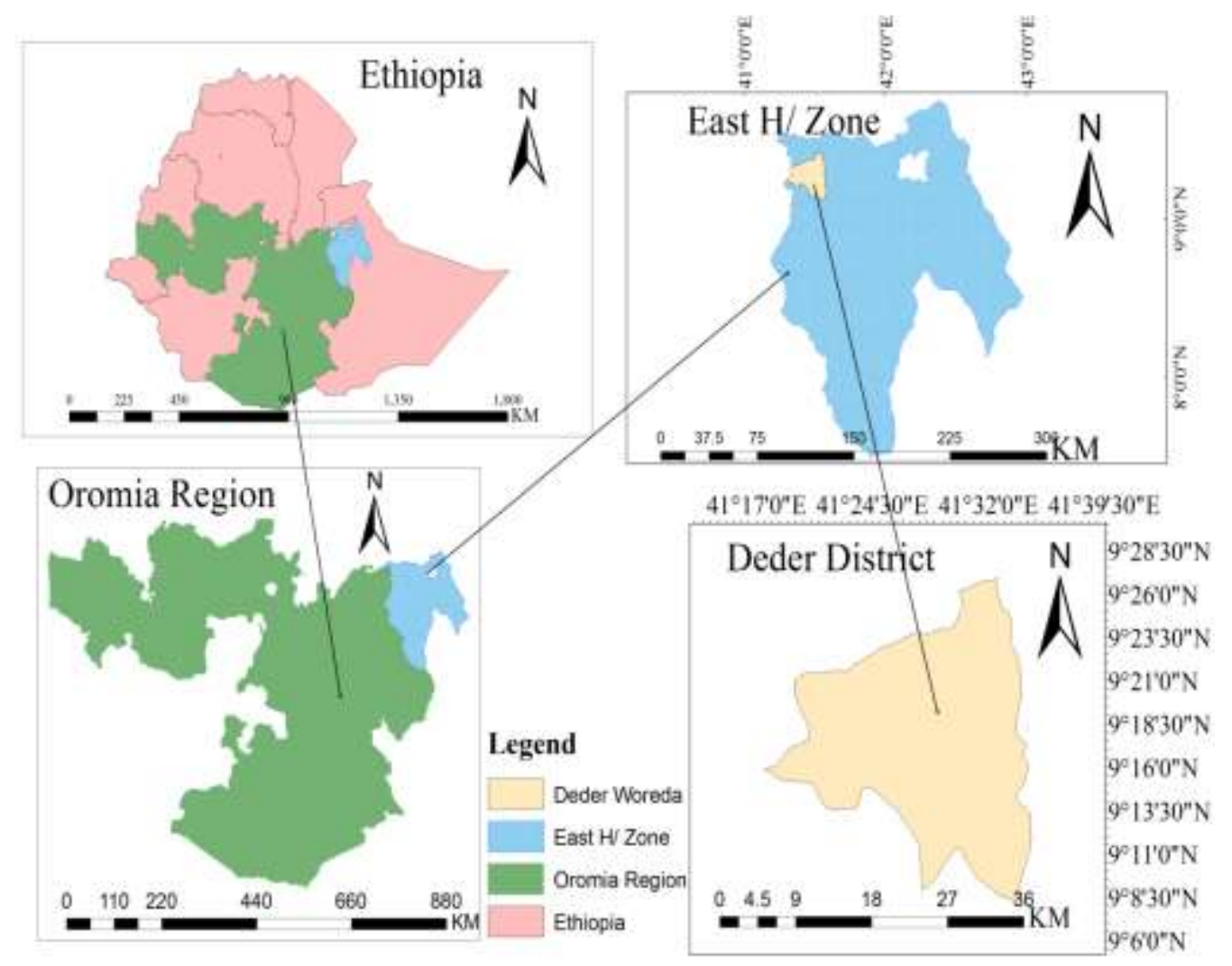

Figure 1:- Map of the study area.

Source: Own Sketch from GIS (2018).

\section{Sample Size and Sampling Method:}

Two stage sampling procedure was used for the selection of sample respondents. In the first stage, out of 37 rural kebeles that are found in Deder district, 28 irrigation user kebeles were purposively identified. Then, due to resource limitations, only four kebeles were selected out of irrigation user kebeles using simple random sampling method. In the second stage, first the household heads in the four sampled kebeles were identified and stratified into two strata: irrigation user and non-user. The sample size regarding each kebeles and stratum were determined using probability proportional to size of the identified households of the selected Kebeles and total users and non-users respectively. Then, the respondents from each stratum were selected using simple random sampling technique. A total of 150 rural households (determined using rule of thumb) were drawn as shown in table 1 below.

Table 1:- Distribution of sample respondents by Kebele.

\begin{tabular}{|l|l|l|l|l|l|l|l|l|l|}
\hline Kebele & $\begin{array}{l}\text { Total } \\
\text { households }\end{array}$ & \multicolumn{2}{l|}{ Strata } & \multicolumn{2}{l|}{ Sample Users } & \multicolumn{2}{l|}{$\begin{array}{l}\text { Sample Non- } \\
\text { users }\end{array}$} & \multicolumn{2}{l|}{ Total samples } \\
\hline & & Users & Non-users & N & $\%$ & N & $\%$ & N & $\%$ \\
\hline Nedigelansedi & 1561 & 1155 & 406 & 37 & 48.7 & 13 & 17.6 & 50 & 33.3 \\
\hline Golu & 1342 & 624 & 718 & 20 & 26.3 & 23 & 31.1 & 43 & 28.7 \\
\hline Nano jalela & 1060 & 343 & 717 & 11 & 14.5 & 23 & 31.1 & 34 & 22.7 \\
\hline Burka geba & 719 & 250 & 469 & 8 & 10.5 & 15 & 20.3 & 23 & 15.3 \\
\hline Total & 4682 & 2372 & 2310 & 76 & 100 & 74 & 100 & 150 & 100 \\
\hline
\end{tabular}


Source: Computed from own data (2018).

Data Type, Source and Collection Methods:

Data were collected from primary and secondary sources. Secondary data was obtained from District Office of Irrigation Development Authority (DIDA), District Agriculture and Natural Resource Office (DANR) and District Livestock Agency (DLA) as well as documentary sources such as published and unpublished documents. The primary data was obtained from primary data sources such as sampled household heads. A cross-sectional survey method was used to collect primary data through a carefully designed semi structured interview schedule using trained enumerators underclose supervision of the researcher.

\section{Methods of Data Analysis:- Descriptive Statistics:}

Descriptive statistics such as mean, standard deviation and frequency of appearance were used to summarize data. The variables hypothesized to affect farmers' participation in small scale irrigation were tested whether they are statistically significant or not using t-test and chi-square $(\chi 2)$ test. The t-test was used to test the significance of the mean value of continuous variables of the two groups of users and non-users. Likewise the potential discrete (dummy) explanatory variables were tested using the chi-square $\left(\chi^{2}\right)$ test.

\section{Econometric Model:}

Considering the need to estimate the selection process in to the irrigation program, the Heckman two stage selection model was employed. This approach was chosen because it considers for selection bias that could arises due to unobservable factor. The common version of the Heckman procedure is to estimate in two stages. In the first stage, estimate the selection or participation equation (the probability of participating in small scale irrigation) using probit model and derives maximum likelihood estimates with data from both participants and nonparticipants.Using the estimation result "Inverse Mills ratio" is constructed. The inverse Mills ratio (lambda) is the tool for controlling bias due to sample selection (Heckman, 1979). The second stage involves including the Inverse Mills ratio as an additional explanatory variable to the household income equation or outcome equation and estimating the equation using OLS model using data from the participant households only. If the coefficient of the 'selectivity' term is significant then the hypothesis that the participation equation is governed by an unobserved selection process or selectivity bias is confirmed. Moreover, with the inclusion of extra term, the coefficient in the second stage 'selectivity corrected' equation is unbiased (Zaman, 2001). Therefore, the researcher has applied Heckman two stage estimation model for this study since it simultaneously model the decision to participate in small-scale irrigation and the effect of small-scale irrigation on the income of households.

\section{Specification of the Econometric ModelUsed:}

In order to achieve both objectives the following functional form was used.

$\mathrm{Pi}=\mathrm{f}\left(\mathrm{Z}_{1}, \mathrm{Z}_{2}, \mathrm{Z}_{3}, \mathrm{Z}_{4} \ldots \mathrm{Z}_{\mathrm{K}}\right)$

The econometric model for the probit model stated in above function equation (1) can be specified as:

$\mathrm{Pi}=\alpha_{0}+\alpha_{1} \mathrm{Z}_{1}+\alpha_{2} \mathrm{Z}_{2}+\ldots+\alpha_{\mathrm{K}} \mathrm{Z}_{\mathrm{K}}+\mu \mathrm{i}$

Where,

$\mathrm{Pi}=$ dichotomous variable representing participation of smallholder farmer households in small-scale irrigation; and it is equal to one if the household participates in small scale irrigation and zero otherwise. $Z_{1}, Z_{2}, Z_{3}, Z_{4} \ldots Z_{K}$ are the vector of variables that affect smallholder farmer households' decision to participate in small scale irrigation. Parameters; $\alpha_{0}, \alpha_{1}, \alpha_{2}, \alpha_{3}, \alpha_{4}, \ldots, \alpha_{\mathrm{K}}$ represents coefficients for the row vectors to be estimated, and $\mu \mathrm{i}$ is the error term.

$\mathrm{Yi}=\mathrm{f}\left(\mathrm{X}_{1}, \mathrm{X}_{2}, \mathrm{X}_{3}, \mathrm{X}_{4} \ldots \mathrm{X}_{\mathrm{K}}\right)$

The econometric model for the outcome model stated in equation (3) can be specified as:

$\mathrm{Yi}=\beta_{0}+\beta_{1} \mathrm{X}_{1}+\beta_{2} \mathrm{X}_{2}+\ldots+\beta_{\mathrm{k}} \mathrm{X}_{\mathrm{k}}+\lambda+\varepsilon \mathrm{i}$

Where,

$\mathrm{Yi}=$ represents the amount of income from small scale irrigation activities. $\mathrm{X}_{1}, \mathrm{X}_{2}, \mathrm{X} 3, \mathrm{X}_{4}, \ldots, \mathrm{XK}$ are determinants of smallholder farm households' small scale irrigation income.

Parameters; $\beta_{0}, \beta_{1}, \beta_{2}, \beta_{3}, \beta_{4, \ldots}, \beta_{\mathrm{k}}$ represent coefficients for the row vectors to be estimated, $\lambda$ is the inverse mills ratio and si is the error term with standard properties.

Let the selection model for household's participation in small scale irrigation be explained by the equation stated below. Here, the equation indicates that household's participation depends on some value pi* of a latent variable.

$\mathrm{Pi}^{*}=\mathrm{Zi} \alpha+\mu \mathrm{i}$ 
Thus, the participation and small-scale irrigation income can be determined from the selection equation as stated below.

$\mathrm{Pi}=\left\{\begin{array}{l}1 \text { if } \mathrm{Pi}^{*}>0 \\ 0 \text { if } \mathrm{Pi}^{*} \leq 0\end{array}\right.$

With the decision to participate in small scale irrigation given by $\mathrm{pi}=1$ if household participate and $\mathrm{pi}=0$ otherwise, where $\mathrm{pi}$ is a variable indicates participation in small-scale irrigation, $\mathrm{Z}$ is a vector of variables that affect households' decision to participate and $\mu \mathrm{i}$ is the corresponding error term. The outcome equation (in this case income from small scale irrigation) is explained as:

yi $=\left\{\begin{array}{c}\mathrm{Xi} \beta+\text { ciifPi }^{*}>0 \\ \text { UnobservableifPi* } \leq 0\end{array}\right.$

\section{Results and Discussion:-}

This chapter presents the main findings of the study regardingsmallholder farmers' participation in small scale irrigation.Theresults are presented and discussedin two main sections based on the objectives of the studywhich are focused on identifyingsocio-economic and institutional factors affecting participation of smallholder farmers in small-scale irrigation and its effect on household irrigation income. The first section presents descriptive statistical results on variables hypothesized to affect participation in small-scale irrigation and income. The Second section presents and discusses results of Econometric model that was used to identify the most important factors that affect small-scale irrigation participation and income in relation to the first and second objectives.

\section{Descriptive Results:}

Sample respondents were composed of both male and female household heads. Out of 76 irrigation user households, $22.4 \%$ are female headed and the remaining $77.6 \%$ are maleheaded. The corresponding figure for non-users is $37.8 \%$ and $62.2 \%$ respectively. The result of chi-square test for sex distribution indicates that there was statistically significant sex difference between irrigation users and non-users at 5\% level of significance.The comparison between user and non-user households showed that $59.2 \%$ of the users and $32.4 \%$ of the non- users have perceived their land as fertile. The result revealed that $85.5 \%$ of the users and $40.5 \%$ of the non-users get extension service. These figures show that majority of the users get support from extension agents when compared to non-irrigators.

Table 2:- Distribution of sample respondents for dummy variables and chi-square test.

\begin{tabular}{|c|c|c|c|c|c|c|c|c|}
\hline \multirow[t]{2}{*}{ Variables } & \multirow[t]{2}{*}{ Values } & \multicolumn{2}{|c|}{ Users (76) } & \multicolumn{2}{|c|}{ Non-users (74) } & \multicolumn{2}{|c|}{ Total sample } & \multirow{2}{*}{$\chi 2$ value } \\
\hline & & No. & $\%$ & No. & $\%$ & No. & $\%$ & \\
\hline \multirow{2}{*}{ Sexhead } & Female & 17 & 22.4 & 28 & 37.8 & 45 & 30 & \multirow{2}{*}{$4.273 * *$} \\
\hline & Male & 59 & 77.6 & 46 & 62.2 & 105 & 70 & \\
\hline \multirow[t]{2}{*}{ persoilfert } & infertile & 31 & 40.8 & 50 & 67.6 & 81 & 54 & \\
\hline & Fertile & 45 & 59.2 & 24 & 32.4 & 69 & 46 & $10.823 * * *$ \\
\hline \multirow[t]{2}{*}{ Acexten } & not accessed & 11 & 14.5 & 44 & 59.5 & 55 & 36.7 & \\
\hline & accessed & 65 & 85.5 & 30 & 40.5 & 95 & 63.3 & $32.674 * * *$ \\
\hline \multirow[t]{2}{*}{ Accredit } & not accessed & 46 & 60.5 & 49 & 66.2 & 95 & 63.3 & \\
\hline & accessed & 30 & 39.5 & 25 & 33.8 & 55 & 36.7 & .523 \\
\hline
\end{tabular}

Source: Computed from own data, (2018).

The average number of economically active family labor force for users and non-users are 7.57 and 3.86 adult equivalent, respectively and that of the total sample is 5.74. The mean difference in active family labor force between irrigation users and non-users is found to be statistically significant at $1 \%$ level of significance.The average land holding of the sampled household is 0.313 hectare. The mean land holding for users is 0.38ha and the corresponding figure for the non-users households is $0.24 \mathrm{ha}$. The variable irrigated land holding is pertinent to users only. Hence, the mean land size allocated for irrigation by user households is $0.192 \mathrm{ha}$ and that of non-user households is 0ha since they are non-participants of small scale irrigation. The mean livestock holding of irrigation users was 2.13TLU while that of the non-users was 0.67TLU. The mean distance of the user households from the water source is $0.48 \mathrm{~km}$ while the corresponding figure for non-users is $3.5 \mathrm{~km}$.

Table 3:- The t-test for mean difference of continuous variables.

\begin{tabular}{|c|c|c|c|c|c|c|c|}
\hline \multirow[t]{2}{*}{ Variables } & \multicolumn{2}{|c|}{ Non-users (74) } & \multicolumn{2}{|c|}{ Users(76) } & \multicolumn{2}{|c|}{ Total sample } & \multirow[b]{2}{*}{$\mathrm{T}$-value } \\
\hline & Mean & St. Dev & Mean & St. Dev & Mean & St. Dev & \\
\hline
\end{tabular}




\begin{tabular}{|l|l|l|l|l|l|l|l|}
\hline Age & 40.74 & 8.53 & 39.24 & 10.49 & 39.98 & 9.57 & -.966 \\
\hline Educ & 3.81 & 3.195 & 4.37 & 2.371 & 4.09 & 2.813 & 1.216 \\
\hline Famlabor & 3.86 & 1.5 & 7.57 & 2.4 & 5.74 & 2.72 & $11.395^{* * *}$ \\
\hline sorcinfo & 1.19 & .99 & 1.43 & .85 & 1.3 & .93 & 1.623 \\
\hline dishom & 3.5 & 1.14 & .48 & .51 & 1.94 & 1.73 & $-20.715^{* * *}$ \\
\hline lundirg & .0000 & NA & .192 & .171 & .0971 & .155 & $9.628^{* * *}$ \\
\hline cultland & .24 & .12 & .38 & .35 & .313 & .273 & $3.24^{* * *}$ \\
\hline dismkt & 1.84 & .68 & 1.7 & .51 & 1.77 & .6 & -1.405 \\
\hline livestock & .67 & .69 & 2.13 & 1.19 & 1.41 & 1.22 & $9.124^{* * *}$ \\
\hline
\end{tabular}

Source: Computed from own survey data, (2018)

Note: represent statistically significant at $1 \%$ significance level

\section{Results of First step Heckman Model (Probit Part):}

The results of the first step of the heckman model showed that out of the total twelve explanatory variables, seven variables of which four are continuous and three are dummies, were found to be significantly determining the irrigation participation decision. Variables found to be significant includes; sex of the household head, distance from households residence to the water source, access to extension service, total livestock holding in tropical livestock unit, availability of family labor force, Size of cultivated land and Perceived Soil fertility statusas presented in table 4 below.

\section{Sex of the household head:}

The results of the econometric model indicate that sex of household head positively affects the probability of participation in SSI and significant at 1\% significance level. The marginal effect of this variable indicates that those male-headed households have 8.7\% more chance of participation in SSI than those female-headed households keeping all other variables constant at their mean value. This result is consistent with Kinfe et al. (2012) that women's access to irrigation is limited in Northern Ethiopia and contrary to the study conducted by Sikhulumile et al. (2014) which found that female headed households are more likely to participate in SSI.

\section{Availability of family labor force:}

The model output shows that family labor force has positive influence on households' decision to participate in SSI and significant at 5\% level of significance. The marginal effect of this variable reveals that as the family labor force increases by one in adult equivalent, the probability of the households' participation in SSI increases by $13.8 \%$, keeping all other variables constant at their mean value. The positive relationship implies that like other parts of Ethiopia, labor is one of the most extensively used inputs of agricultural production in the study area. Participation in SSI demands additional labour force for different farming operations such as land preparation, planting, fertilizer application and watering. Sikhulumile et al. (2014) and Kalkidan (2016) also reported that labor availability is crucial factor influencing households' decision to involve in SSI.

\begin{tabular}{|l|l|l|l|l|}
\hline Explanatory variables & Coefficient & Std. Err. & Z Value & Marginal effects \\
\hline Age & -.0971777 & .0711394 & -1.37 & -.0306586 \\
\hline Sexhead & .2196424 & .0773617 & $2.84^{* * *}$ & .0874255 \\
\hline Educ & .5340534 & .3268422 & 1.63 & .2111861 \\
\hline Famlabor & .3480337 & .1758089 & $1.98^{* *}$ & .1376265 \\
\hline Sorcinfo & .1641883 & .2502226 & 0.66 & .0653528 \\
\hline Dishom &. .4514538 & .2149736 & $-2.10^{* *}$ & -.1785229 \\
\hline Cultland & .7072309 & .2177767 & $3.25^{* * *}$ & .2815031 \\
\hline Dismkt & -.0648006 & .0729858 & -0.89 & -.025793 \\
\hline Persoilfert & .5419949 & .2743735 & $1.98^{* *}$ & .2111345 \\
\hline Livestock & .4278142 & .1358 & $3.15^{* * *}$ & .1691749 \\
\hline Acexten & .5587219 & .3015168 & $1.85^{*}$ & .2200123 \\
\hline Accredit & .0540651 & .3420169 & 0.16 & .0213259 \\
\hline Cons & -4.524617 & 1.064891 & $-4.25^{* * * *}$ & \\
\hline Dependent variable & Irrigation Participation Decision & & \\
\hline Number of observations & 150 & \multicolumn{4}{l|}{} \\
\hline LR chi2 (12) & 71.70 & \\
\hline
\end{tabular}




\begin{tabular}{|l|l|}
\hline Prob> chi & \\
\hline Pseudo ${ }^{2}$ & 0.0000 \\
\hline Log likelihood & 0.3449 \\
\hline
\end{tabular}

Table 4:- Results of first step estimates of heckman model and its marginal effect.

Source: model output (2018)

Note: $* * *$ and $* * *$ : refers to significance at $10,5 \%$ and $1 \%$ level, respectively.

Distance of households' residence from the water source:

This variable is statistically significant at 5\% and influence SSI participation decision negatively. The marginal effect shows that as the distance from the farmers' residence to the water source decreases by one kilometer, the probability of participation in SSI increases by $17.8 \%$, keeping all other variables constant at their mean value. This implies that the farther households' residence from the water source, the lesser would be farmers' probability to participate in SSI. Kinfe et al. (2012) also reported that household's residence to water sources have a significant and negative relationship to in participation in SSI.

\section{Size of cultivated land:}

The result reveals that farm size positively influences the probability to participate in SSI and significant at $1 \%$ significance level. The marginal effect of this variable indicates that as the size of cultivated land increases by one hectare, the probability of participation in SSI increases by $28 \%$, keeping all other variables constant at their mean value. This result is consistent with the finding of Mohammed and Jema (2013) who also obtained that farm size influenced the household heads decision to participate in SSI.

\section{Perceived Soil fertility status:}

The results indicate that the perceived Soil fertility status has a positive influence on SSI participation and statistically significant at $5 \%$ level of significance. This means that only those farmers who perceived their land as fertile expect better yields and have motivation to participate in SSI farming as they incur cost in the process. The marginal effect reveals that those farmers who perceived their soil as fertile have $21 \%$ more chance of participation in SSI than those who felt that their soils were infertile keeping all other variables constant at their mean value. This result is consistent with results of Bacha et al. (2011) and Tesfaye et al. (2008) who found that farmers who perceived their land as fertile have more initiation to participate in SSI.

\section{Total livestock holding:}

Livestock holding, measured in tropical livestock unit, has a positive effect on the probability of participation in SSI and significant at $1 \%$ level of significance. This indicates that households with more livestock holding are able to participate in the irrigation activity as compared to those with less livestock holding. The marginal effect shows that as the number of livestock in TLU increases by one, the probability to participate in SSI increases by $16.9 \%$, keeping all other variables constant at their mean value. The same result was reported by Desale (2008) that livestock holding has positive influence on participation in SSI.

\section{Access to extension services:}

The study result reveals that access to extension service influences smallholder farmers' decision to participate in SSI positively and statistically significant at $10 \%$ level of significance. This implies that agricultural extension services have a critical role to play in motivation of farmers towards the adoption of improved irrigation practices. The marginal effect shows that those households who have access to extension service have $22 \%$ more chance of participation in SSI than households who have no access to extension service, keeping all other variables constant at their mean value. Gebregziabher et al. (2009) also reported that household heads with higher extension service are more likely to participate in SSI.

\section{Estimates of Heckman Two Step Model for Outcome Variable:}

Out of the total twelve explanatory variables, six variables are found to be significant factors affecting household irrigation income. These are sex of the household head, land under irrigation, availability of family labor force, total livestock holding, access to extension service and the inverse Mills ratio (lambda). The effect of the significant explanatory variables on smallholder farmers' income level is discussed below. 


\section{Sex of the household head:}

The study result indicates that this variable is statistically significant at $1 \%$ significance level and the coefficient of this variable also shows that those male headed households earn 5005.2 birr more total income as compared to those female headed households keeping all other variables constant. This means that male headed households have higher income as compared to female headed households. This result is consistent with the result of Kalkidan (2016) that male headed households' irrigation income is significantly higher than that of female headed households.

\section{Land under irrigation:}

The model result indicates that land under irrigation has positive influence on household income and significant at $1 \%$ significance level. The coefficient of the variable shows that an increase in irrigated land of a household by one hectare increases total irrigation income of the households by Birr 35826.5. This implies that irrigating large areas of land can help to increase production and incomes by minimizing crops failures due to water scarcities. This result is consistent with the findings of Eshetu et al. (2010)who found that land under irrigation has a positive and significant influence on household's irrigation income.

\section{Availability of family labor force:}

The study revealed that active family labor force has a positive influence on household irrigation income and statistically significant at 5\% level of significance. The coefficient of this variable shows that asactive family labor force in adult equivalent increases by one,thetotal irrigation income of the household would be increased by Birr 1622.3 keeping all other variables constant.This shows that households with larger family labor force can perform various irrigation activities in order to properly manage irrigated plot and earn higher annual irrigation income. This result is consistent with the findings of Kinfe et al. (2012) that availability of family labor force has positive and significant influence on irrigation income.

\section{Total livestock holding:}

The model output shows that livestock holding in Tropical Livestock Unit (TLU) has a positive influence on income of households, and statistically significant at $5 \%$ level of significance. The coefficient of the variable revealed that, a unit increase in livestock holding in TLU would increase the total irrigation income of a household by Birr 2952.4, keeping all other variables constant. This means that besides its direct contributions to household income, Livestock holding in tropical livestock unit supports investment in irrigation farming and crop production activities. It helps for application of modern farm inputs such as improved seeds, chemical fertilizers, and agrochemicals which increase agricultural productivity. This result is consistent with results reported by Kinfe et al. (2012) that livestock holding measured in Tropical Livestock Unit have a positive and significant influence on household's income.

\section{Access to extension service:}

Extension service has positive effect on household irrigation income and statistically significant at $1 \%$ level of significance. The positive association indicates that those households who have access to extension service are willing to adopt new irrigation technologies and improving the household level of income. The coefficient of this variable indicates that the total irrigation income of households who have access to extension service would be higher by Birr 1455 as compared to households who have no access to extension service keeping all other variables constant. Therefore, agricultural extension service is essential for the development of small scale irrigation agriculture through adapting and introducing improved agricultural technologies and hence, helping to increase household irrigation income. This result is also in line with the findings of Almaz et al. (2014)that access to extension service has positive and significant influence on irrigation income.

Table 5:- Heckman two stage estimates for the outcome equation.

\begin{tabular}{|l|l|l|l|}
\hline Explanatory variables & Coefficient & Std. Err. & Z value \\
\hline Cons & 28805.66 & 14584.8 & $1.98^{* *}$ \\
\hline Age & -71.45645 & 212.7166 & -0.34 \\
\hline Sexhead & 5005.172 & 1879.883 & $2.66^{* * *}$ \\
\hline Educ & 59.11096 & 333.5904 & 0.18 \\
\hline Famlabor & 1622.274 & 719.1722 & $2.26^{* *}$ \\
\hline Sorcinfo & 443.6165 & 596.332 & 0.74 \\
\hline Dishom & -204.6869 & 2372.129 & -0.09 \\
\hline Lundirg & 35826.48 & 8429.76 & $4.25^{* * *}$ \\
\hline
\end{tabular}




\begin{tabular}{|l|l|l|l|}
\hline Dismkt & -27.92519 & 327.7126 & -0.09 \\
\hline Persoilfert & 340.5177 & 2122.414 & 0.16 \\
\hline Livestock & 2952.434 & 1276.491 & $2.31^{* *}$ \\
\hline Acexten & 1455.02 & 539.8901 & $2.70^{* * *}$ \\
\hline Accredit & 197.2844 & 354.1051 & 0.56 \\
\hline Lambda & 8.119074 & 3.625179 & $2.24^{* *}$ \\
\hline Dependent variable & household irrigation annual income & & \\
\hline Number of observations & 150 & & \\
\hline Censored observations & 74 & & \\
\hline Uncensored observations & 76 & & \\
\hline Wald chi2 (12) & 166.04 & & \\
\hline Prob> chi2 & 0.0000 & & \\
\hline
\end{tabular}

Source: model output (2018)

Note: $* *$ and $* * *$ refers to significance at $5 \%$ and $1 \%$ level, respectively

\section{Conclusions and Recommendations:-}

In relation to household's participation decisionin small scale irrigation, the study findings indicate a relationship between smallholder farmers'decision to participatein small scale irrigation and variables such as sex of household head, Family labor force,Distance of households' residence from the water source, Size of cultivated land, Perceived Soil fertility status, Total livestock holding measured in tropical livestock unitand Access to extension service.This suggests that smallholder farmers' decision to participate in small-scale irrigation is being affected by different factors. Likewise, the study finding also shows the relationship between household irrigation income and variables such as sex of household head, Family labor force, total livestock holding in tropical livestock unit, Access to extension service and Land under irrigation. This implies that household's irrigation income is being influenced by multiple factors. Based on these findings, the following recommendation can be drawn for further consideration and improvement of irrigation development and income in the study area.

The result indicated that the likelihood of participation and income of female headed households are less than the male headed households. Therefore, it is better if both government and non-government organizations working in the study area mainstream gender to ensure gender equity and empowerment in order to enable female headed households participate in small scale irrigation and enhance their income. Family labor problems can be solved by introducing innovative and labor saving technologies through labor multiplication as a replacement of human labor for households with shortage of labor for intensive production. Therefore, it is good if agricultural engineering research centers, micro-finance institutions and extension organizations work together to generate and distribute those technologies to farmers in the study area in order to enhance irrigation participationand household income. Distance of the irrigation scheme affects use of irrigation negatively. Therefore, it is better if both government and non-government organizations, who are responsible for the construction of small scale irrigation schemes, consider the distance of residences during the construction and development of small scale irrigation schemes for a better use of irrigation water by users. Access to extension services was positively and significantly related to both farm households' participation in small-scale irrigation and income. Hence, it is good if agricultural faculties of Ethiopian Universities and colleges train development agents especially irrigation experts with best quality and in sufficient number to enhanceextension services forfarming societies.

The study revealed that the number of livestock holding in TLU influence participation decision in small-scale irrigation and income positively and significantly. For that reason, it is virtuous if the livestock sector give due attention to feed resource improvement and management, genetic resource improvement as well as protection and prevention of animal diseases. Since expansion of cultivation land is impossible in the study area, it is better if farmers intensively use the existing land to mitigate the problem of land scarcity. For this purpose, farmers should be encouraged to use intensive agricultural production methods. In this regard, the current effort of the government to promote small-scale irrigation scheme and water harvesting technologies should be further expanded and strengthened in order to enhance production and productivity at farm level. 


\section{References:-}

1. AlmazGiziew, WorkinehNigatu, Edilegnaw Wale and GezehagnAyele. (2014): Constraints of Vegetables Value Chain in Ethiopia: A gender Perspective. International Journal of Advanced Research in Management and Social Sciences, 3(12): 44-71.

2. Asayehegn, K. (2012): Negative impact of small-scale irrigation schemes: A case study of Central Tigray regional state, Ethiopia. Journal of Agricultural Research and Reviews, 1(3): 80-85.

3. Awulachew, S. B., Merrey, D., Van Koopen B., and Kamara, A. (2010): Roles, Constraints and Opportunities of Small-Scale Irrigation and Water Harvesting in Ethiopian agricultural Development: Addis Ababa, Ethiopia: International Water Management Institute (IWMI).

4. Awulachew, S.B., Ayana, M. (2011): Performance of irrigation: an assessment at different scales in Ethiopia. Journal of Experimental Agriculture, 47(1): 57-69.

5. Bacha, D., Namara, R., Bogale, A., \&Tesfaye, A. (2011): Impact of Small-Scale Irrigation on Household Poverty: Empirical Evidence from the Ambo District in Ethiopia. Journal of Irrigation and Drainage, 60(1): 110.

6. Desale, S. (2008): Determinants of farmers' participation in Micro-finance Institutions and their savings' magnitude in West Shewa zone. MSc Thesis, Haramaya University, Haramaya, Ethiopia.

7. Eshetu, S., Belete, B., Goshu, D., Kassa, B., Tamiru, D., Worku, E. (2010): Income Diversification through Improved Irrigation in Ethiopia: Impacts, Constraints and Prospects for Poverty Reduction. Evidence from East Harerghe Zone, OromiaRegion, Ethiopia. Overseas Development Institute, Research Inspired Policy and Practice Learning in Ethiopia and the Nile Region (Ripple), Working Paper 14, Ethiopia.

8. FAO (Food and Agricultural Organization). (2014): Ethiopia country programming framework Revised Document.

9. FAO (Food and Agricultural Organization). (2015): A Review of Ethiopian Agriculture: Roles, Policy and Small-scale Farming Systems. Ministry of Agriculture, Addis Ababa, Ethiopia.

10. Ferris, S. (2014): Linking smallholder farmers to markets and the implications for extension and advisory services. Available on: http//infoagro.net/archivos_Infoagro/Infotec/biblioteca/EN_MEASBrief4 LinkingFa.pdf Accessed May 12, 2017.

11. Gebregziabher, G., Namara, R., \& Holden, S. (2009): Poverty reduction with irrigation investment: An empirical case study from Tigray, Ethiopia. Journal ofAgricultural Water Management, 96(1): 1837-1848.

12. Heckman, J. (1979): Sample selection bias as a specification error. Econometrica, 47: 153-162.

13. IWMI (International Water Management Institution). (2005): Working Paper 98, Experiencing and Opportunities for Promoting Small scale/Micro Irrigation and Rainwater Harvesting for Food Security in Ethiopia.

14. Jayne, T.S.; K. Chance, and I. Minde. (2017): Enhancing United States efforts to develop sustainable agri-food systems in Africa. Paper commissioned by Farm Journal Foundation. http://www.farmersfeedingtheworld.org/policy-briefing/.

15. KalkidanFikirie. (2016): The Role of Gender in Small Scale Irrigation Agriculture among Smallholder Farmers inLume District inthe Central Rift Valley of Ethiopia. MSc Thesis, Hawassa University, Wondo Genet, Ethiopia.

16. Kinfe, A., Chilot, Y., \&Rajan, S. (2012): Effect of small-scale irrigation on the income of rural farm households: the case of LaelayMaichew district, central Tigray, Ethiopia. Journal of Agricultural Science, 7(1): 1.

17. Martey E., Asante O., Al-Hassan R., Dogbe, C. (2013): Factors influencing participation in rice development projects. The case of small holder rice farmers in northern Ghana. International Journal of Development and Economic Sustainability, 1(2): 13-27

18. MoA (Ministry of Agriculture). (2011): Small-Scale Irrigation Capacity Building Strategy for Ethiopia. Published by Natural Resources Management Directorate.

19. Mohammed, A., Jema, H. (2013): Impact analysis of Mede Telila small scale irrigation scheme on house poverty alleviation: Case of Gorogutu District in Eastern HaratgheOromia National Regional State Ethiopia. International Journal of Development and Economic Sustainability, 1(1): 15-30.

20. Mutambara, S., Mutambara, J., Darkoh, M.B.K. (2014): Towards sustainable stakeholder engagement in smallholder irrigation schemes in Zimbabwe. African Journal of Agricultural Research, 9(50): 3587-3599.

21. Namara, R.E., Horowitz, L., Nyamadi, B., Barry, B. (2011): Irrigation Development in Ghana: Past Experiences,

22. Emerging Opportunities and Future Directions. International Food Policy Research Institute, Accra,Ghana.

23. Pinstrup, A. and Watson, D. (2011): The role of government in Global, National and Local food systems: Food 
24. policy for developing countries. Cornell University. Driving forces of food system Policy Brief series, Brief 13.

25. Sikhulumile, S., Mudhara, M., \& Wale, E. (2014): The impact of smallholder irrigation on household welfare: The case of Tugela Ferry irrigation scheme in KwaZulu-Natal, South Africa. . International. Journal of Water Resource Development, 20(2): 243-257.

26. Spielman D., Byerlee D., Avid J., Alemu D., Kelemework D. (2010): Policies to promote cereal intensification in Ethiopia: The search for appropriate public and private roles, Food Policy, 35(1): 185-194.

27. Tesfaye, A., Bogale, A., Namara, R., \&Bacha, D. (2008): The impact of small-scale irrigation on household food security: The case of Filtino and Godino irrigation schemes in Ethiopia. Journal of Irrigation Drainage Systems, 22(2): 145-158.

28. Todaro, M. (2012): Economic Development $11^{\text {th }}$ Edition. New York University. Developing countries-Economic policy. Addison-Wesley publisher, USA.

29. World Bank. (2010): Ethiopian Agricultural Growth Project. Project appraisal document. Addis Ababa, Ethiopia.

30. Zaman, H. (2001): Assessing the poverty and vulnerability impact of micro credit in Bangladish: A case study of BRAC. Office of the chief economist and senior vice president (DECVP). The World Bank. 34-36. 